\begin{tabular}{|c|c|c|c|c|c|c|c|}
\hline \multirow{2}{*}{$\begin{array}{l}\text { Series } \\
\text { or } \\
\text { Mixed }\end{array}$} & \multirow{2}{*}{$\begin{array}{l}\% \text { Tri } \\
-i s o- \\
\text { buty- } \\
\text { lene }\end{array}$} & \multicolumn{4}{|c|}{ Specific retention volume } & \multirow{2}{*}{$\begin{array}{c}\text { No. of } \\
\text { Theoreti- } \\
\text { cal } \\
\text { Plates } \\
\text { for } \\
\text { Propy- } \\
\text { lene }\end{array}$} & \multirow{2}{*}{$\begin{array}{c}\text { Reten- } \\
\text { tion } \\
\text { time } \\
\text { from } \\
\text { injection } \\
\text { for } \\
\text { Propy- } \\
\text { lene }\end{array}$} \\
\hline & & Fthane & $\begin{array}{l}\text { Ethy- } \\
\text { lene }\end{array}$ & $\begin{array}{l}\text { Pro- } \\
\text { pane }\end{array}$ & $\begin{array}{l}\text { Propy- } \\
\text { lene }\end{array}$ & & \\
\hline - & nil & 0.14 & $10 \cdot 4$ & 0.14 & $15 \cdot 6$ & $\longrightarrow$ & min. \\
\hline- & 100 & $5 \cdot 2$ & $3 \cdot 2$ & $22 \cdot 1$ & $\begin{array}{l}10 \cdot 0 \\
20 \cdot 5\end{array}$ & 二 & - \\
\hline Series & $49 \cdot 3$ & $2 \cdot 5$ & $6 \cdot 8$ & $10 \cdot 7$ & $17 \cdot 3$ & 1012 & $8 \cdot 4$ \\
\hline Mixed & $47 \cdot 2$ & $2 \cdot 5$ & $7 \cdot 6$ & $10 \cdot 6$ & $17 \cdot 9$ & 1134 & 8.8 \\
\hline Series & $27 \cdot 2$ & $1 \cdot 3$ & $9 \cdot 0$ & $5 \cdot 7$ & 17.0 & 990 & $7 \cdot 1$ \\
\hline Mixed & $23 \cdot 5$ & $1 \cdot 2$ & $9 \cdot 8$ & $5 \cdot 1$ & $17 \cdot 3$ & 1075 & $7 \cdot 1$ \\
\hline
\end{tabular}

of the column(s) immediately after use. Operating conditions: support, 85-100 mesh 'Celite'; stationary phase, 1 part approximately to 4 of support ; column temperature, $12^{\circ} \mathrm{C}$. (tap water); inlet pressure, $5 \mathrm{~cm}$. of mercury (gauge) for single $4-\mathrm{ft}$. columns, $10 \mathrm{~cm}$. for combined 8-ft. columns; outlet pressure, atmospheric; carrier gas, nitrogen, approximately $20 \mathrm{ml}$. per min.; detector, hydrogen flame (temp.)

The ethylene glycol/silver nitrate contained 27 per cent by weight of silver nitrate. A saturated solution at $12^{\circ} \mathrm{C}$. contains about 42 per cent $w / w$. The triisobutylene was old stock and contained approximately 5 per cent of an acid calculated as $\mathrm{C}_{12}$. A study of Fig. 1 and Figs. $1 a$ and $1 b$ in Barnard and Hughes ${ }^{1}$ communication suggests that their 'series' column contained practically no triisobutylene and that their "mixed" column contained about 10 per cent triisobutylene and 90 per cent ethylene glycol/silver nitrate. Triiso. butylene is appreciably volatile, and in our experiments it was found that the mixing operations caused a loss of about 10 per cent on a total of $2.5 \mathrm{gm}$. Our experiments were done at $12^{\circ} \mathrm{C}$. merely to allow more precise measurement of the rather short retention times. A check at $25^{\circ} \mathrm{C}$. showed that the differences from relative retention volumes at $12^{\circ} \mathrm{C}$. for the same column were not very great, but ethane and hydrogen were not well separated which made precise measurement difficult.

I wish to thank the Directors of the Distillers Company limited for permission to publish this communication.

The Distillers Company Ltd.,

Great Burgh, Epsom, Surrey.

1 Barnard J. A., and Hughes, H. W. D., Nature, 183, 250 (1959).

\section{Use of Tritium to Study the Solubility of Water in Hydrocarbons}

THE use of tritiated water as a radioactive tracer to study the solubility of water in hydrocarbons clearly offers many advantages, especially the fact that low concentrations of water in a hydrocarbon can be easily and accurately assayed by liquid scintillation counting. We have adopted this technique to make a closer study of how well Henry's Law is obeyed for such a system. Black, Joris and Taylor ${ }^{1,2}$ used tritium with a gas counting technique for a similar investigation and assumed, along with others $^{3}$, that Henry's Law was followed up to saturation point. In the discussion of the latter paper $^{3}$ some evidence was put forward to suggest that substantial deviations from Henry's Law were observed for water dissolved in hydrocarbon fuels. More recently Englin et al. ${ }^{4}$ have published results substantiating the original assumptions. 'The work described below using the more sensitive techniques of liquid scintillation counting of HTO as a tracer is claimed to be the most accurate study of the waterhydrocarbon system to date.

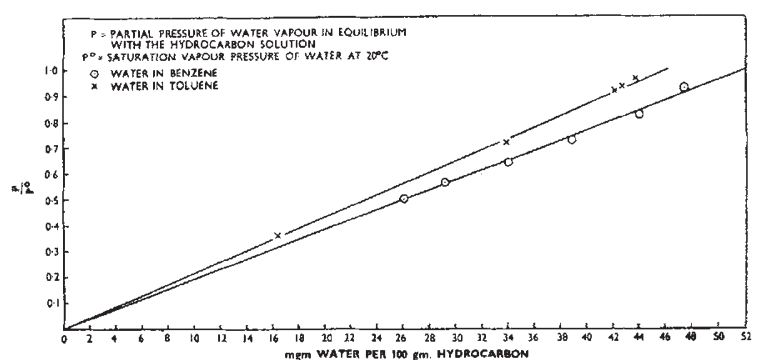

Fig. 1. Solubility of Water in Benzene and Toluene at $20^{\circ} \mathrm{C}$.

A stream of dry air was saturated with tritiated water at temperature $T_{1}$ and was allowed to come to equilibrium with the hydrocarbon liquid at temper ature $T_{2}\left(T_{2}>T_{1}\right)$. Samples were taken of the hydrocarbon after equilibration and counted after dissolving in a liquid phosphor.

By varying $T_{1}$ and keeping $T_{2}$ constant it was possible to obtain a series of values of equilibrium water solubilities corresponding to different water vapour partial pressures. It is convenient to express the vapour pressure data as the function $p / p_{0}$ where $p=$ water vapour pressure at $T_{1}$ and $p_{0}=$ water vapour pressure at $T_{2}$. These values were calculated having ascertained experimentally that the saturator and the air steam velocity were such as to ensure saturation at temperature $T_{1}$. Typical results are given for benzene and toluene in $\mathrm{Fig}$. 1 showing that there is virtually no deviation from Henry's Law up to saturation. Saturation solubilities at $20^{\circ} \mathrm{C}$. of water in benzene and toluene are found to be 52 $\mathrm{mgm} . / 100 \mathrm{gm}$. and $46 \mathrm{mgm} . / 100 \mathrm{gm}$. respectively. The value for toluene compares very favourably with that obtained by Englin et al. ${ }^{4}$ (48 mgm./100 gm.).

Precautions were taken to ensure that equilibrium conditions were established during the experiments. For calibration purposes the specific activity of the air stream in equilibrium with the hydrocarbon was determined. This was done by condensing out the water vapour and counting it under identical conditions to those pertaining to the counting of the hydrocarbon samples. Under these conditions it was lower by 15 per cent than that of the original water in the saturator ; this was due to the isotope effect of tritium. The data given in Fig. 1, however, refer to the behaviour of water, which of course assumes that any isotope effect of water and tritiated water, when dissolved in a hydrocarbon, is negligible.

The liquid scintillation counter used was a single channel instrument. By giving special attention to the design of the sample cell used to contain the liquid phosphor it was possible to operate at room temperature for all the experiments described above. The maximum counting efficiency for non-quenching tritium samples was 12 per cent over a background of 300 c.p.m.

We would like to express our thanks to the Directors of 'Shell' Research Ltd. for permission to publish this letter.

Thornton Research Centre,

B. D. CADDOCK

P. L. Davies

'Shell' Research Ltd.,

rhornton-le-Moors, Chester.

1 Joris, G. G., and Taylor, H. S., J. Chem. Phys., 16, 45 (1948).

2 Black, C., Joris, G. G., and Taylor, H. S., J. Chem. Phys., 16, 537 Davies, P. I., Fourth World Petroleum Congress Section V/E, 427

4 Englin, B. A., Tuglolukov, v. M., Sakodynskaya T. భ., Khimiya $i$ Tekhnologiya Topliva, 11, 43 (1956). 